\title{
Timing of DAA Initiation After Curative Treatment and Its Relationship with the Recurrence of HCV-Related HCC
}

This article was published in the following Dove Press journal:

Journal of Hepatocellular Carcinoma

\author{
Xiuzhu Gao $\mathbb{D}^{1,2, *}$ \\ Mengru Zhan (D) ${ }^{1, *}$ \\ Liquan Wang ${ }^{3}$ \\ Yanhua Ding ${ }^{2}$ \\ Junqi Niu'
}

'Department of Hepatology, First Hospital of Jilin University, Changchun, Jilin I3002I, People's Republic of China; ${ }^{2}$ Phase I Clinical Research Center, The First Hospital of jilin University, Changchun, Jilin I3002I, People's Republic of China; ${ }^{3}$ Imaging Department, Jilin Province Occupational Disease Prevention and Treatment Hospital, Changchun, Jilin Province 130102,

People's Republic of China

*These authors contributed equally to this work
Correspondence: Yanhua Ding Phase I Clinical Research Center, The First Hospital of Jilin University, 7I

XinMin Street, Changchun, Jilin I3002I,

People's Republic of China

$\mathrm{Tel} / \mathrm{Fax}+86-43 \mathrm{I}-8 \mathrm{I} 875 \mathrm{I} 03$

Email dingyanhua2003@|26.com

Junqi Niu

Department of Hepatology, First Hospital of Jilin University, 7I Xin Min Street,

Changchun, Jilin I3002I, People's

Republic of China

$\mathrm{Tel} / \mathrm{Fax}+86-43 \mathrm{I}-8 \mathrm{I} 875103$

Email junqi_niu@I63.com

\begin{abstract}
Hepatitis $\mathrm{C}$ virus infection is a major cause of chronic hepatitis, leading to cirrhosis and hepatocellular carcinoma (HCC). Many studies agree that interferon (IFN)based antiviral therapy can reduce the risk of $\mathrm{HCC}$ recurrence in patients with chronic hepatitis $\mathrm{C}$ who have achieved a sustained virological response (SVR). The recent introduction of direct-acting antivirals (DAA) has resulted in excitingly high SVR rates. However, as an IFN-free regimen, DAAs only exert antiviral activity without an immune response. The benefit of DAA-based regimens for $\mathrm{HCC}$ recurrence in patients with cirrhosis and following successful curative treatment remains controversial. Additionally, the time span between curative-intent therapy and the DAA regimen is an independent risk factor for HCC recurrence, irrespective of the DAA response. HCC patients who are eligible for potentially curative therapy by liver resection or ablation should defer DAA therapy; however, the accurate timing remains unclear. In this study, we reviewed the timing of DAA initiation after curative treatment and its effect on the recurrence of related HCC.
\end{abstract}

Keywords: DAA, HCC, HCV, recurrence, curative treatment, cirrhosis

\section{Introduction}

$\mathrm{HCC}$ is the seventh most common cancer and fourth leading cause of cancer deaths worldwide, ${ }^{1}$ accounting for more than $90 \%$ of liver cancer cases. ${ }^{2}$ Approximately 78,200 individuals are diagnosed with liver cancer every year, and the annual number of deaths globally is estimated at approximately $0.4-0.6$ million. Globally, an estimated 71 million individuals have chronic hepatitis $\mathrm{C}$ virus infection, ${ }^{3}$ and cirrhosis caused by chronic hepatitis $\mathrm{C}$ virus (HCV) infection is one of the most common risk factors for $\mathrm{HCC}{ }^{4}$ The onset of liver cancer is often hidden. Nearly half of patients with HCV are currently unaware of their infection due to the suboptimal rates of HCV screening. Some patients are asymptomatic, and physical examination lacks the signs of the tumor itself. Once the symptoms appear, most of the patients have entered the middle and late stages. Liver cancer usually has a poor prognosis, placing a huge burden on families and society.

Although many treatment methods are available for HCC, surgical resection remains the primary method. However, the HCC recurrence rate is very high, with an annual rate of $15 \%-20 \%$, a high rate not observed with other malignant neoplasms, resulting in a high mortality, ${ }^{5,6}$ even after curative procedures, including surgical resection. The intrahepatic recurrence of HCC is generally divided into 
early (within 2 years) and late (beyond 2 years) recurrence. Early recurrence usually comprises either microscopic metastases of the primary cancer or local recurrence of previously treated cancer. Late recurrence is due to the multicentric carcinogenic process driven by underlying liver cirrhosis. ${ }^{7}$ Hepatectomy can induce liver regeneration, leading to $\mathrm{HCC}$ growth. A recent meta-analysis showed that the 6-month and 2-year pooled HCC recurrence rates were $7.4 \%$ and $47.0 \%$ in HCV-related HCC patients who were not unexposed to DAA. ${ }^{8}$ These data indicate an urgent need for an effective adjuvant strategy that can reduce $\mathrm{HCC}$ recurrence.

Recurrence after curative resection of HCC developed from multicentric origins, which are closely related to the $\mathrm{HCV}$ viremia status. ${ }^{7}$ Over the last few decades, the primary anti-HCV treatment was pegylated interferon (Peg IFN) combined with ribavirin. Many findings reported that a positive response could significantly reduce the risk of HCC occurrence and recurrence. ${ }^{9-11}$ However, contraindications and severe side effects limited its application. ${ }^{12}$

New highly effective, IFN-free, direct-acting antivirals (DAAs) have revolutionized HCV treatment, with high rates of a sustained virologic response (SVR) in a very short time, ${ }^{13-15}$ even for patients infected with HCV genotype 3, and very few side effects have been reported compared with IFN-based therapy. ${ }^{16}$ Gamal Shiha reported the incidence of HCC was reduced in chronic hepatitis C genotype 4 patients with cirrhosis who achieved SVR following DAA therapy. ${ }^{17}$ This therapeutic option has increased the confidence in a drastic decline in HCC occurrence, even in patients with prior liver cancer. However, the appropriate timing of DAA initiation after surgical resection of $\mathrm{HCV}$-related $\mathrm{HCC}$ patients and the effect of DAA on HCC recurrence remain controversial. Studies evaluating DAA and the risk of HCC recurrence after a complete response to resection have produced conflicting data, and some studies have suggested a decreased risk of HCC recurrence after DAA, while others have shown opposite results. The AGA Clinical Practice Update on Interaction Between Oral Direct Acting Antivirals recommends that patients with HCC who are eligible for potentially curative therapy with liver resection or ablation should defer DAA therapy until after HCC treatment is completed. ${ }^{18}$ Additionally, evidence on HCVrelated $\mathrm{HCC}$ recurrence after HCV eradication by DAAs in previously cured patients is equivocal. The uncertainty concerning the optimal management of patients with DAA after resection may lead to confusion among doctors.
Overall, with the advent of the DAA era, how to maximize the role of DAA is currently the top priority. This review aimed to summarize the timing of DAA initiation after resection surgery and clarify the effect of the time window between DAA initiation and resection on the recurrence of HCV-related HCC.

\section{Timing of DAA Initiation After Curative Treatment and Its Effect on HCC Recurrence}

A surprisingly high rate of early HCC recurrence after DAA therapy post curative treatment observed by Reig et al for 20 DAA-treated HCV patients with a 5.7-month follow-up caused widespread concern about the benefit of DAA for HCC. ${ }^{19}$ Based on this study, Pei-Chien Tsai and colleagues found that the recurrence rate was significantly higher among patients with a time lag within 4 months (54.6\%) than among those with a time lag of more than 4 months $(21.3 \%){ }^{20}$ Singal et al, based on a multicenter cohort study in North American of $111 \mathrm{HCV}$ patients with 10.4 months (5.3-20.8) of DAA initiation, revealed that the risk of early recurrence could differ according to the initiation time of DAA therapy. The proportions of patients with HCC recurrence were $44.0 \%$ for those with a duration from HCC CR to DAA initiation of less than 3 months, $50.0 \%$ for those with a duration from HCC CR to DAA initiation of 4-6 months, and $36.9 \%$ for those with a duration of DAA initiation more than 6 months, but these values did not achieve statistical significance. ${ }^{21}$ Zavaglia et al observed only 1 case of HCC recurrence among 31 that had received curative treatment and then started DAA therapy; the low recurrence rate was partly due to the longer interval between the curative procedures and DAA initiation. ${ }^{22}$ Ogawa et al reported the results of multivariable Cox analysis of $152 \mathrm{HCV}$-related HCC patients, and the time between previous $\mathrm{HCC}$ treatment and DAA exposure within 1 year (HR: 3.20; 95\% CI: $1.29-9.65 ; \mathrm{P}=0.0011)$ was significantly associated with HCC recurrence. ${ }^{23}$ However, Singal, A.G and colleagues reported that patients with prior $\mathrm{HCC}$ had a median time from the HCC complete response to DAA initiation of 7.7 (IQR 3.6-14.1) months, and DAA therapy was associated with a significant reduction in the risk of death. ${ }^{24}$ In a systematic review with a meta-analysis, Saraiya et al suggested an acceptable HCC recurrence rate after DAA therapy that was delayed at least 6 months after the HCC complete response. ${ }^{25}$ Adhoute et al found that, compared 
with patients without recurrence, the time interval between HCC treatment and DAA initiation in patients with HCC recurrence was shorter $[36.0$ months vs 7.0 months $(\mathrm{P}=0.0235)$, respectively]. ${ }^{26}$ In multivariate analysis of $163 \mathrm{HCV}$-related HCC patients, Minami et al found a longer interval ( $>2$ years) between the last HCC treatment and DAA initiation that was significantly associated with reduced recurrence (HR:0.34; $\mathrm{P}=0.009$ ). ${ }^{27}$ Kolly $\mathrm{P}$ confirmed that patients with a longer timeframe between HCC CR and DAA prescription had a lower risk HCC recurrence (HR: 0.908; $\mathrm{P}=0.001){ }^{28}$

Interestingly, Kogiso et al reported that $\mathrm{HCC}$ recurred after a median of 22.0 months of DAA treatment, whereas those without recurrent HCC had 16.1 months of DAA treatment. No significant difference was found in the starting time of DAA between the HCC recurrent and nonrecurrent groups. $^{29}$ This result was supported by Degasperi et al, although HCC recurred in $7 / 17$ (41\%) patients starting $\mathrm{DAA} \leq 6$ months from previous $\mathrm{HCC}$ treatment versus $13 / 43(30 \%)$ patients starting DAA treatment $>6$ months $(\mathrm{P}=0.54)$, time interval between $\mathrm{HCC}$ treatment and DAA start could not predict $\mathrm{HCC}$ recurrence at univariate analysis. $^{30}$

As suggested by several studies, the early recurrence of HCC may not be related to whether to use DAA but likely to the time of DAA initiation. Some studies believed that the short interval between curative treatment and DAA may cause a high rate of early HCC recurrence. Since most clinical trials did not include HCC patients, the data on SVR rate of DAAs on HCV-related HCC and the risk of $\mathrm{HCC}$ recurrence mainly come from retrospective cohorts and real-world studies. Chang, C.Y found in a retrospective study of 110 consecutive Asian Americans with $\mathrm{HCV}$ genotypes 1 to 3 or 6 treated with IFN-free SOF-based regimens, after receiving DAAs, the total SVR rate was as high as $93 \%$, while the SVR rate of HCC patients without curative treatment was only $82 \%{ }^{30}$ A study of $421 \mathrm{HCV}$-related cirrhosis patients included $33 \%$ of cases with active HCC or a history of HCC. After DAAs treatment, the SVR of cirrhosis patients without $\mathrm{HCC}$ was $88 \%$, while that with $\mathrm{HCC}$ was $79 \%$. There was a statistical difference between the two groups. ${ }^{31}$ Persico, M showed that active tumor was a risk factor for DAAs treatment failure. After the remission of $\mathrm{HCC}$, the efficacy of DAAs was similar to that of patients without HCC in a multivariate analysis. ${ }^{32}$ Many studies have confirmed that for patients who are found to be HCVrelated $\mathrm{HCC}$, curative treatment include resection, radiofrequency ablation, liver transplantation and radiotherapy followed by DAAs can increase SVR, reduce the risk of liver cancer recurrence and improve overall survival. $^{24,33-35}$ All of the above, considering that HCC patients do not require antiviral therapy immediately after curative procedures, for safety reasons, the existing guidelines and clinical practice believe that appropriate delay of DAA treatment can prolong the time for immune surveillance to work and allow a sufficient time to verify an HCC complete response, thereby minimizing the chance of misclassification bias. The American Gastroenterology Association clinical practice recommended that patients with complete remission after HCC undergoing liver resection or ablation should receive DAAs treatment, and the DAAs treatment time can be 4-6 months after surgery. ${ }^{18}$ German Alliance for Liver Cancer (GALC) recommended DAA therapy should start 6-12 (at the earliest) after HCC with curative intent. ${ }^{36}$ So far, since the current studies lack randomized controlled studies (RCT), long-term follow-up, and so on, the timing of DAA treatment is still inconclusive, and further research is needed.

\section{DAA Therapy Increases the Risk of Recurrence in Patients with Previous HCV-Related HCC with Curative Treatment}

Some of the earliest studies reported that DAA might have a negative impact on the risk of recurrence in patients with previous HCV-related HCC with curative treatment. Reig reported the early tumor recurrence of $20 \mathrm{HCV}$ patients with a complete response after a history of HCC treated by ablation, resection or chemoembolization as $27.6 \%$, and the recurrence rate in patients with a short interval between HCC treatment and DAA therapy is $41.17 \%{ }^{19}$ DAA might have a negative impact on immune surveillance, so individuals older than 50-60 years must be carefully screened before undergoing DAA. However, the evidence in this study was limited by the small number of subjects and lack of an untreated control arm, as well as a series of methodological concerns not addressed by the authors, for example, a combination of heterogeneous groups of patients who received different treatments, including palliative and curative management. A similar high recurrence rate of HCC was found in Conti et al's study: $28.8 \%$ of cirrhotic patients with a history of previous liver cancer showed HCC recurrence within a short period of 24 weeks of follow-up. Even more difficult to 
explain was that 17 patients with a median HCC-free interval of 446 days at DAA initiation showed HCC recurrence within a few months after DAA treatment. ${ }^{37}$ Additionally, the preliminary report of Warzyszynska $\mathrm{K}$ showed that HCC recurrence rates in the DAA group $(\mathrm{N}=19)$ and NDAA (non-DAA) group $(\mathrm{N}=32)$ were $42.1 \%$ and $65.6 \%$, respectively $(\mathrm{P}=0.058)$, with a relapse time significantly earlier in the DAA group than in the NDAA group (256 vs 532 days after surgery; $\mathrm{P}<0.05)$. Additionally, compared with the NDAA group, the RFS rate in the DAA group was lower, confirming that the application of DAA therapy in patients with a history of HCC may result in a significantly accelerated HCC relapse. ${ }^{38}$ In this material, before treatment, the mean AFP level in the DAA group was significantly higher than that in the NDAA group (139.2 mg/dl vs $32.4 \mathrm{mg} /$ dl), likely explaining the higher recurrence rate in the DAA group. A meeting abstract from Japan reported that in the 11.4-month median follow-up period, 9 in 36 patients developed tumor recurrence $(25 \%)$ after DAA therapy that presented unexpected clinical courses. ${ }^{39}$ During the same year, Tokoro et al showed an extremely high $\mathrm{HCC}$ recurrence rate (59\%) within a 16.2-month follow-up time in a cohort of 22 patients. ${ }^{40}$

Some of the aforementioned studies merely observed the effect of DAA therapy on HCC recurrence, which ignored the time lag between $\mathrm{CR}$ (complete response, defined as no evidence of HCC following 2 consecutive imaging assessments performed 1 and 3 months after previous HCC treatment) and DAA initiation. Although they were corrected for potential confounding, they still had the pharmacovigilance effect. Researchers who had high hopes for DAA began to calm down and thought about the possible reasons for the high $\mathrm{HCC}$ recurrence after DAA therapy. Because DAAs are the accepted standard of care even in patients with previously treated early $\mathrm{HCC}$, it is not feasible or ethical to design randomized controlled trials (RCTs) using an NDAA cohort as the control.

\section{DAA Therapy Cannot Increase the Risk of Recurrence in Patients with Previous HCV-Related HCC with Curative Treatment}

However, the negative view of DAA is questioned by subsequent studies showing that DAA therapy cannot increase the risk of recurrence in patients with previous HCV-related HCC with curative treatment. DAA therapy was associated with a lower recurrence risk in patients who achieved CR after resection, but without statistical significance (HR: 0.61; 95\% CI: 0.28-1.32). ${ }^{21}$ Cabibbo et al showed that, in the DAA group, the HCC recurrence rate was lower than that in the NDAA group, although the difference was not statistically significant (HR: $0.70 ; 95 \%$ CI: 0.44-1.13; $\mathrm{P}=0.15$ ) in a multicenter prospective cohort study. Notably, despite HCC recurrence, DAA can improve survival in $\mathrm{HCV}$-cirrhotic patients and reduce the risk of hepatic decompensation. ${ }^{33} \mathrm{~A}$ recent study found that after antiviral therapy, the IFN group had better 1-, 3-, and 5-year RFS (relapse-free survival) than the DAA group ( $95 \%$ vs $75.4 \%$; $\mathrm{P}<0.001)$. Even after propensity score-matching model analysis, the DAA group still had higher HCC recurrence rates than the IFN group. Another issue to consider is that there were no recurrences within 3 months after complete tumor necrosis; however, after the prescription of DAA therapies, 4 (4.8\%) and 13 (15.5\%) patients showed HCC recurrence within 3 and 6 months, respectively, but no patient cured by IFN-based regimens developed HCC recurrence within 6 months. Nevertheless, Kuo et al reported that the DAA group had better tumor RFS than the untreated group. ${ }^{41}$ A large prospective cohort of HCV-cirrhotic patients with previous successfully treated early HCC reported that the probability of HCC early recurrence remains high despite DAA exposure but not higher than that reported in the literature in DAA-untreated patients. ${ }^{8,42}$ However, these data contained high variability in HCC early recurrence due to the indirect comparison between DAA-exposed and unexposed patients. Kogiso et al confirmed that DAA did not increase the rate of $\mathrm{HCC}$, even in patients who received immunosuppressive therapy in a retrospective study. ${ }^{29}$ A study comprising three prospective multicenter cohorts, with different patient profiles, including cirrhotic and noncirrhotic patients, showed that DAAs could not increase the risk of HCC recurrence, even in patients who had undergone liver transplantation. ${ }^{43}$ Adhoute et al showed that DAA treatment did not affect the incidence of HCC recurrence, although it likely could not prevent the early recurrence of $\mathrm{HCC}$ in one case-control study. ${ }^{26}$ Lin et al found that, although DAA therapy improved the survival outcome of HCC patients, no correlation was found between DAA treatment and recurrent $\mathrm{HCC}$ in a retrospective study. ${ }^{44}$ Mashiba et al found no difference in the recurrence rate of HCC patients treated with interferon and DAA in a multicenter study cohort, reflecting the real-world data in Japan. ${ }^{45}$ However, DAA treatment 
may reduce the second recurrence following curative treatment after the first recurrence in a landmark time analysis. ${ }^{46}$ This finding aligned with previous results reporting that interferon treatment can reduce the second relapse but not the first relapse. ${ }^{47-50}$ A meeting abstract by Urabe A, S.R published in Hepatology showed that, compared with the IFN group, although the cumulative incidence of HCC in the DAA group was lower at 6 and 12 months after the start of antiviral therapy, no difference was found in early HCC recurrence after 18 months of antiviral therapy between IFN-based and IFN-free therapy for patients. ${ }^{51}$ Granata et al reported that, after DAA treatment, the recurrence rate was $27.8 \%$ with a 7 -month (range:3-15 months) follow-up period, indicating that the eradication of $\mathrm{HCV}$ did not reduce the risk of $\mathrm{HCC}$ recurrence in a prospectively single-center study. ${ }^{52} \mathrm{~A}$ nationwide multicenter study conducted by the Japanese Red Cross Hospital Liver Study Group found no difference in early recurrence between DAA-treated and IFN-treated patients, and accurate data were not shown. ${ }^{53}$ Waziry et al found no difference in the recurrence rate of HCC after DAA treatment and interferon treatment in a systematic review, meta-analyses, and meta-regression that recruited 17 qualified studies. ${ }^{54}$ Additionally, Shinichiro reported that the recurrence rate in patients treated with DAAs after curative treatment of HCC was comparable to that before the DAA era, ${ }^{55}$ confirming the concept that DAA therapy is not related to HCC development.

\section{DAA Therapy Decreases the Risk of Recurrence in Patients with Previous HCV-Related HCC with Curative \\ Treatment}

Additionally, DAA therapy is thought to decrease the risk of recurrence in patients with previous HCV-related HCC with curative treatment. Kolly et al found that DAA treatment reduced $\mathrm{HCC}$ recurrence risk (HR: 0.894; 95\% CI: $0.827-0.965 ; \mathrm{P}=0.004$ ) in a European multicenter study of 47 patients, with a mean follow-up period of 21.5 months. ${ }^{56}$ Another comment by Torres et al found that no patient $(\mathrm{N}=20)$ who received curative procedures followed by DAA showed recurrent $\mathrm{HCC}$ over a median follow-up period of 12 months (range, 4-60 months). ${ }^{57}$ Another study observed only 1 case of neoplastic recurrence in our series of 31 consecutive patients whose HCC was previously cured with a median follow-up time of 8 months. The author Zavaglia et al explained the cause might be the longer interval between complete eradication of the tumor and initiation of DAA (median of 19.3 months vs 11.2 months in Reig's study). ${ }^{19,22}$ The data extracted from Reig's study showed 6-month, 1-year, 2-year, 3-year and 5-year recurrence rates of $5.2 \%$, $12.9 \%, 26.3 \%, 33.5 \%$ and $39.1 \%$, respectively, in patients with SVR achieved following IFN-free treatment. These values were significantly lower those for patients without antiviral treatment. The median times to recurrence in the DAA-treated group and HCV activated group were 31 months and 72 months, respectively. ${ }^{58}$ Virlogeux et al showed that the median times between HCC remission and recurrence in DAA-treated patients and untreated patients were 17.4 months and 10.1 months, respectively. Additionally, a significant difference was found in the $\mathrm{HCC}$ recurrence rate in DAA-treated patients and untreated patients $(73.3 \%$ vs $47.8 \%)$ in a retrospective cohort study of 68 patients. ${ }^{59}$ Preda et al confirmed that DAA therapy positively impacted the recurrence rate, which was significantly lower in the DAA resection + RFA group $(\mathrm{N}=12)$ than that in the control resection + RFA group $(\mathrm{N}=12): 5.5 \%$ versus $24.6 \% \quad(\mathrm{P}=0.044)$. Even considering TACE, compared with the untreated group, the HCC recurrence rate/100 patient-years of the entire group of patients treated with DAAs was considerably reduced. ${ }^{60}$ Nagata et al showed that the 5-year cumulative $\mathrm{HCC}$ recurrence rates after $\mathrm{HCV}$ eradication was similar between IFN-based and DAA-based therapies $(54.2 \%$ vs $45.1 \% ; \mathrm{P}=0.54){ }^{61}$ A DAA cohort and an untreated HCV-related HCC cohort with similar backgrounds, including age, gender, liver function, number of tumors, and Child-Pugh score, confirmed that DAA therapy significantly decreased the recurrence rate of $\mathrm{HCC}{ }^{62}$ Sangiovanni A confirmed that DAA treatment could decrease the incidence of $\mathrm{HCC}$ recurrence in $\mathrm{HCV}$ cirrhotic patients who achieved SVR in a multicenter prospective trial of 111 patients in Italy. ${ }^{63}$ The recurrence rates within 2 years were $55 \%, 55 \%$ and $35 \%$ in the DAA, IFN and control groups, respectively. These results did not significantly differ among the three groups $(\mathrm{P}=0.38)$, and the cumulative RFS rates at 6,12 , and 24 months in the DAA group were higher than those in the IFN and untreated groups, achieving significance $(\mathrm{P}=0.045)$ and indicating the positive attitude toward DAA therapy. ${ }^{64}$ Imai et al found that, compared with the untreated group $(\mathrm{N}=64)$, the DAA $(\mathrm{N}=13)$ and IFN groups $(\mathrm{N}=14)$ could increase RFS, but was no difference was 
found between the DAA and IFN groups. ${ }^{65}$ The more details are available in Table 1.

\section{Discussion}

The emergence of DAA is a milestone in anti-HCV treatment. ${ }^{66-68}$ More than $95 \%$ of $\mathrm{HCV}$ patients can achieve SVR regardless of genotype. Additionally, its excellent safety and higher efficacy enable the treatment of $\mathrm{CHC}$ patients with advanced fibrosis and cirrhosis. Early clinical trials in the interferon era have confirmed that SVR could significantly improve the outcome and reduce the risk of decompensated liver cirrhosis and HCC. ${ }^{69-71}$ Therefore, providers and patients have high hopes for DAA in terms of reducing the incidence and recurrence rates of HCC and are eager to launch related clinical observations. However, studies have reported the high unexpected recurrence rate of HCC in patients receiving DAA treatment. ${ }^{19,37}$ Coincidentally, not only were the recurrence rates were estimated to be higher but some findings warned that the incidence of HCC was also higher than expected. ${ }^{72,73}$ By contrast, some studies have reported that DAA treatment cannot increase the risk of HCC recurrence. ${ }^{22,56-59,61,62,65}$ The above results heightened the discussion regarding the benefit of DAA in HCC patients.

The conflicting data may be due to the heterogeneity and discrepancies among the obtained results. The causes of the variability in the available data can be summarized as follows: (1) different study designs: retrospective, prospective, or case-control studies or meta-analyses; (2) different study settings: single-center, multi-center or real-world, nationwide or international studies; (3) inclusion and exclusion criteria; (4) basic information about the subject, such as gender, age, BMI, genotype of HCV virus; (5) tumor characteristics, including the diameter, number, whether the tumor has metastasis and the number of HCC recurrences; (6) risk factors such as alcohol abuse and diabetes; (7) interval between curative treatment and DAA therapy; (8) type of curative HCC treatment; (9) lack of a control group or inconsistent inclusion time between the control and experimental groups; (10) use of other medications before DAA treatment; (11) inconsistent follow-up time. Compared with the interferon group, patients in the DAA treatment group were older and had more advanced liver cirrhosis. These are independent risk factors that affect $\mathrm{HCC}$ recurrence, ${ }^{74}$ this can explain the high risk of HCC recur in DAA group. Additionally, the follow-up start time differed among the studies. Some started from the initiation of DAA therapy, some started from the end of DAA therapy, and some started from the $\mathrm{HCC}$ complete response. The significant variability in the timing of follow-up is a major area of potential bias. The HCV eradication of the HCC recurrence risk is difficult to evaluate because of the high heterogeneity. Therefore, designing more scientific and rational clinical trials, as well as more detailed subgroup analysis to obtain less bias between different groups, is warranted.

Furthermore, unlike IFN, which attacks HCV-infected hepatocytes through an immune response to achieve $\mathrm{HCV}$ inhibition with an anti-tumor effect, DAA directly inhibits HCV virus replication. ${ }^{75}$ The sudden decline in HCV after DAA may cause the imbalance of the immune system, leading to the reduction of immune surveillance and the immune-killing effect on tumors, leading to tumor recurrence. A Belgian study observed a high early recurrence rate of HCC in patients treated with DAA without IFN compared with their PEG-IFN+DAA counterpart, although the DAA monotherapy group showed a higher risk of HCC at baseline. ${ }^{76}$ Furthermore, HBV rebound was reported in $\mathrm{HCV}$ and $\mathrm{HBV}$ coinfected patients after DAA treatment. $^{77-79}$

Another noteworthy issue is that, compared with nonSVR patients, the HCC recurrence rate in patients with SVR after IFN treatment is significantly reduced, but the recurrence rate remains unsatisfactory, indicating that the elimination of $\mathrm{HCV}$ virus is far from reaching the endpoint of treatment. ${ }^{80-84}$ Many studies have confirmed that the elimination of HCV can improve liver function and prolong the survival time of HCC patients, but the reduction in the recurrence rate of liver cancer is not optimistic. The possible reason may be that DAA drugs cannot inhibit the progression of precancerous lesions to malignant tumors, so DAA cannot reduce the recurrence rate of early liver cancer. Recurrent HCC can occur at the time of DAA initiation, causing an overestimation of the post-DAA HCC recurrence. Therefore, it is particularly important to review CT or MRI every 3-4 months. Based on the patient's age, sex, presence of liver cirrhosis, alcohol consumption, AFP level and number of recurrences of liver cancer, the interval between re-examinations should be shortened or extended.

Although different opinions exist regarding the effect of DAA on HCC recurrence, the underlying mechanism on hepato-carcinogenesis, tumor recurrence and progression by DAA remains unclear. Some experts still recommend for patients with HCC to undergo DAA at an appropriate time after curative treatment because they believe the benefit improved liver function and prolonged survival by DAA 
Table I Characteristics of Studies Concerning the HCC Recurrence Rates of HCV-Related HCC Patients with Curative Treatment After DAA Therapy

\begin{tabular}{|c|c|c|c|c|c|c|}
\hline Author & $\mathbf{N}$ & $\begin{array}{l}\text { N (\%) } \\
\text { Receiving } \\
\text { DAA }\end{array}$ & $\begin{array}{l}\text { Follow- } \\
\text { Up } \\
\text { (Months) }\end{array}$ & HCC Recurrence Rate & $\begin{array}{l}\text { Curative } \\
\text { Treatment }\end{array}$ & $\begin{array}{l}\text { Time Between } \\
\text { HCC Remission } \\
\text { and DAA Initiation } \\
\text { (Months) }\end{array}$ \\
\hline María Reig ${ }^{19}$ & 20 & $20(100 \%)$ & 5.7 & $7 / 20$ (35\%) & $\begin{array}{l}\text { Resection: } 36 \% \\
\text { Ablation: } 53 \% \\
\text { TACE: } 10 \%\end{array}$ & 11.2 months \\
\hline Conti $\mathrm{F}^{37}$ & 19 & $19(100 \%)$ & 6 & $8 / 19$ (42.1\%) & $\begin{array}{l}\text { Resection: } 32 \% \\
\text { Ablation: } 41 \% \\
\text { TACE: } 8 \% \\
\text { Multimodal: } 17 \%\end{array}$ & 12.4 months \\
\hline $\begin{array}{l}\text { Karola } \\
\text { Warzyszyńska }{ }^{38}\end{array}$ & 51 & 19 (37.3\%) & NA & $\begin{array}{l}\text { DAA vs NDAA: } \\
47.3 \% \text { vs } 75 \% P=0.45 \\
\text { I-year RFS rate }\end{array}$ & NA & NA \\
\hline Amit $G$ Singal $^{21}$ & III & $64(57.6)$ & 10.4 & $\begin{array}{l}\text { HR: } 0.6 \mathrm{I} \\
95 \% \mathrm{Cl}: 0.28-\mathrm{I} .32\end{array}$ & NA & $\begin{array}{l}\text { I0.4 months (IQR: } \\
5.3-20.8)\end{array}$ \\
\hline $\begin{array}{l}\text { Giuseppe } \\
\text { Cabibbo }^{33}\end{array}$ & 204 & $102(50 \%)$ & 21.4 & $\begin{array}{l}\text { DAA vs NDAA: } \\
6 \text { months: } 6 \% \text { vs } 9 \% \\
\text { I year: } 15 \% \text { vs } 20 \% \\
2 \text { years: } 27 \% \text { vs } 40 \% \\
3 \text { years: } 70 \% \text { vs } 57 \% \\
P=0.15\end{array}$ & $\begin{array}{l}\text { DAA vs NDAA: } \\
\text { Resection: } \\
34(33.3 \%) \text { vs } 36 \\
(35.3 \%) \\
\text { RFA: } 68(66.7 \%) \text { vs } \\
66(64.7 \%)\end{array}$ & $\begin{array}{l}2.1 \text { months (range: } \\
0.5-6 \text { months) }\end{array}$ \\
\hline $\begin{array}{l}\text { Giuseppe } \\
\text { Cabibbo }^{42}\end{array}$ & 143 & $143(100 \%)$ & $8.7(3-19)$ & $\begin{array}{l}6 \text { months: } 12 \% \\
12 \text { months: } 26.6 \% \\
18 \text { months: } 29.1 \%\end{array}$ & $\begin{array}{l}\text { Surgical resection: } 52 \\
\text { (36.4\%) } \\
\text { Thermal ablation: } 66 \\
\text { (46.1\%) } \\
\text { TACE: } 25 \text { (17.5\%) }\end{array}$ & $11(1-126)$ \\
\hline E Ogawa $^{23}$ & 152 & $152(100 \%)$ & $17(I-23)$ & $\begin{array}{l}\text { No cirrhosis vs cirrhosis: } \\
6.5 \% \text { vs } 23.1 \% \mathrm{P}=0.023 \\
\text { I-year cumulative } \mathrm{HCC} \text { recurrence rate }\end{array}$ & $\begin{array}{l}\text { Resection: } 60 \\
(39.5 \%) \\
\text { Resection + RFA: } 6 \\
(3.9 \%) \\
\text { RFA: } 49 \text { (32.2\%) } \\
\text { RFA + TACE: I3 } \\
(8.6 \%) \\
\text { TACE: } 22 \text { (14.5\%) } \\
\text { Particle radiotherapy: } \\
2 \text { (I.3\%) }\end{array}$ & 1.2 years \\
\hline Amit G Singal $\left.\right|^{24}$ & 797 & $383(48 \%)$ & NA & $\begin{array}{l}\text { DAA vs untreated: } \\
209(54.6 \%) \text { vs } 205(50.7 \%) \\
\text { HR } 0.86(0.49-1.52)\end{array}$ & $\begin{array}{l}\text { DAA vs untreated: } \\
\text { Resection: } 8 \text { I } \\
(21.2 \%) \text { vs I } 38 \\
(36.0 \%) \\
\text { RFA: I } 36(35.5 \%) \text { vs } \\
28(7.3 \%) \\
\text { TACE: } 33(8.0 \%) \text { vs } \\
\text { I } 30(31.4 \%) \\
\text { Other: } 222(53.8 \%) \\
\text { vs } 28(6.8 \%)\end{array}$ & $\begin{array}{l}7.7 \text { (IQR: 3.6-I4.I) } \\
\text { months }\end{array}$ \\
\hline
\end{tabular}

(Continued) 
Table I (Continued).

\begin{tabular}{|c|c|c|c|c|c|c|}
\hline Author & $\mathbf{N}$ & $\begin{array}{l}\text { N (\%) } \\
\text { Receiving } \\
\text { DAA }\end{array}$ & $\begin{array}{l}\text { Follow- } \\
\text { Up } \\
\text { (Months) }\end{array}$ & HCC Recurrence Rate & $\begin{array}{l}\text { Curative } \\
\text { Treatment }\end{array}$ & $\begin{array}{l}\text { Time Between } \\
\text { HCC Remission } \\
\text { and DAA Initiation } \\
\text { (Months) }\end{array}$ \\
\hline $\begin{array}{l}\text { Tomomi } \\
\text { Kogiso }^{29}\end{array}$ & 45 & 45 (100\%) & $\begin{array}{l}25.9 \\
(2.7-4 I .3)\end{array}$ & $\begin{array}{l}33 \% \\
\text { Median interval until HCC recurrence } \\
\text { after DAA: II.6 months (range: } 2.2-34.2 \\
\text { months) }\end{array}$ & $\begin{array}{l}\text { Resection: } 25 \% \\
\text { RFA: } 35 \% \\
\text { TACE: } 11 \% \\
\text { LT: } 6 \%\end{array}$ & $16.3(2.1-242.5)$ \\
\hline $\begin{array}{l}\text { Stanislas Pol } \\
\text { ANRS CO22 } \\
\text { HEPATHER } \\
\text { cohort }^{43}\end{array}$ & 267 & $\begin{array}{l}189 \\
(70.8 \%)\end{array}$ & $\begin{array}{l}\text { DAA vs } \\
\text { untreated: } \\
20.2 \text { vs } \\
26.1 \\
\text { after DAA } \\
\text { initiation }\end{array}$ & $\begin{array}{l}\text { DAA vs untreated: } \\
24(12.7 \%) \text { vs } 16(20.5 \%) \\
0.73 / 100 \text { vs } 0.66 / 100 \mathrm{P}=0.8756 \\
\text { person-months } \\
\text { First } 3 \text { months of the treated period }\end{array}$ & NA & NA \\
\hline $\begin{array}{l}\text { Stanislas Pol } \\
\text { ANRS COI } 2 \\
\text { CIRVIR } \\
\text { cohort }^{43}\end{array}$ & 79 & $13(16.5 \%)$ & $\begin{array}{l}\text { DAA vs } \\
\text { untreated: } \\
16.5 \text { vs } \\
22.1 \\
\text { after DAA } \\
\text { initiation }\end{array}$ & $\begin{array}{l}\text { DAA vs untreated: } \\
\text { I }(7.7 \%) \text { vs } 3 \mid(47 \%) \\
\text { I.I I/I00 vs } 1.73(100) P=0.748 \\
\text { person-months } \\
\text { First } 3 \text { months of the treated period }\end{array}$ & NA & NA \\
\hline $\begin{array}{l}\text { Xavier } \\
\text { Adhoute }^{26}\end{array}$ & 71 & $22(31 \%)$ & $\begin{array}{l}\text { DAA vs } \\
\text { NDAA: } \\
68 \text { vs } 32\end{array}$ & $\begin{array}{l}\text { DAA vs untreated: } \\
41 \% \text { vs } 35 \% P=0.7904 \\
\text { during follow-up period }\end{array}$ & $\begin{array}{l}\text { DAA vs untreated: } \\
\text { Transplantation: } 3 \\
\text { (14\%) vs } 5 \text { (10\%) } \\
\text { Resection/ablation } \pm \\
\text { TACE: } 13(59 \%) \text { vs } 24 \\
(49 \%) \\
\text { TACE: } 6 \text { (27\%) vs } 20 \\
(41 \%)\end{array}$ & $12(6-38)$ \\
\hline Wei Chen $\operatorname{Lin}^{44}$ & 59 & 35 (59\%) & $20(I I-26)$ & $\begin{array}{l}\text { DAA vs NDAA: } \\
37.1 \% \text { vs } 45.8 \% \mathrm{P}=0.278 \\
\text { during the follow-up period }\end{array}$ & NA & $\begin{array}{l}24 \text { months (IQR: } \\
\text { I5-48 months) }\end{array}$ \\
\hline $\begin{array}{l}\text { Satoshi } \\
\text { Miuma }^{46}\end{array}$ & 76 & $17(22.3)$ & NA & $\begin{array}{l}\text { NDAA vs DAA: } \\
76.3 \% \text { vs } 47.1 \% \mathrm{P}=0.115 \\
\text { during the follow-up period }\end{array}$ & $\begin{array}{l}\text { NDAA vs DAA: } \\
\text { Surgery: } 2 \text { I (35.6\%) } \\
\text { vs } 5 \text { ( } 29.4 \%) \\
\text { RFA: } 35(59.3 \%) \text { vs } 9 \\
(52.9 \%) \\
\text { SRT: } 3(5.1 \%) \text { vs } 3 \\
(17.6 \%)\end{array}$ & $0.72(0.31-10.4)$ \\
\hline $\begin{array}{l}\text { Toshie } \\
\text { Mashiba }^{45}\end{array}$ & 516 & $368(71.3)$ & $\begin{array}{l}\text { IFN vs } \\
\text { DAA: } \\
25.5 \text { vs } 7.7\end{array}$ & $\begin{array}{l}\text { No difference in early recurrence } \\
\text { between DAA-treated and IFN-treated } \\
\text { patients }\end{array}$ & NA & $333(15 \pm 5038)$ \\
\hline R Bielen ${ }^{76}$ & 42 & $42(100 \%)$ & 12 months & $\begin{array}{l}\text { PEG-IFN+DAA vs DAA: } \\
0 \% \text { vs } 15 \% P=0.857\end{array}$ & $\begin{array}{l}\text { LT: } 2 \mathrm{I} / 4 \mathrm{I}(5 \mathrm{I} .2 \%) \\
\text { Resection: } 10 / 4 \mathrm{I} \\
(24.4 \%) \\
\text { RFA: } 9 / 4 \mathrm{I}(22.0 \%) \\
\text { TACE: I/4I (2.4\%) }\end{array}$ & $\begin{array}{l}\text { PEG-IFN+DAA vs } \\
\text { DAA: } \\
\text { II vs } 33 \pm 47 \text { months }\end{array}$ \\
\hline
\end{tabular}

(Continued) 
Table I (Continued).

\begin{tabular}{|c|c|c|c|c|c|c|}
\hline Author & $\mathbf{N}$ & $\begin{array}{l}\text { N (\%) } \\
\text { Receiving } \\
\text { DAA }\end{array}$ & $\begin{array}{l}\text { Follow- } \\
\text { Up } \\
\text { (Months) }\end{array}$ & HCC Recurrence Rate & $\begin{array}{l}\text { Curative } \\
\text { Treatment }\end{array}$ & $\begin{array}{l}\text { Time Between } \\
\text { HCC Remission } \\
\text { and DAA Initiation } \\
\text { (Months) }\end{array}$ \\
\hline Philippe Kolly ${ }^{56}$ & 47 & 47 (100\%) & 21.5 & $\begin{array}{l}\text { HR: } 0.894 \\
95 \% \text { Cl: } 0.827-0.965\end{array}$ & NA & NA \\
\hline $\begin{array}{l}\text { Harrys } \\
\text { A Torres }\end{array}$ & 8 & $8(100 \%)$ & $12(4-60)$ & 0 & $\begin{array}{l}\text { Resection: } 50 \% \\
\text { Ablation: } 38 \% \\
\text { Proton therapy: } 12 \%\end{array}$ & 7.5 months \\
\hline $\begin{array}{l}\text { Claudio } \\
\text { Zavaglia }^{22}\end{array}$ & 31 & $31(100 \%)$ & 8 & $3.2 \%$ & $\begin{array}{l}\text { Resection: } 42 \% \\
\text { Ablation: } 19 \% \\
\text { TACE: I } 3 \%\end{array}$ & 19.3 months \\
\hline S Petta ${ }^{58}$ & 58 & $58(100 \%)$ & $18(3-90)$ & $12.9 \%$ & NA & NA \\
\hline $\begin{array}{l}\text { Victor } \\
\text { Virlogeux } 59\end{array}$ & 68 & $23(34 \%)$ & $\begin{array}{l}\text { DAA vs } \\
\text { NDAA: } \\
35.7 \text { vs } \\
15.4\end{array}$ & $\begin{array}{l}\text { DAA vs NDAA: } \\
\text { II/23 ( } 47.8 \%) \text { vs } 33 / 45(73.3 \%) \\
1.7 / 100 \text { person-months vs } 4.2 / \\
100 \text { person-months } \\
\mathrm{P}=0.008\end{array}$ & $\begin{array}{l}\text { Radiofrequency } \\
\text { ablation: } 43 \text { (63\%) } \\
\text { Chemoembolization } \\
\text { +conformal } \\
\text { radiotherapy: } 5(7 \%) \\
\text { Chemoembolization: } \\
2(3 \%) \\
\text { Surgical resection: } 10 \\
(15 \%) \\
\text { different treatment } \\
\text { combinations: } 8 \\
(12 \%)\end{array}$ & $\begin{array}{l}7.2 \text { months } \\
(0.3-71.4)\end{array}$ \\
\hline $\begin{array}{l}\text { Yuan-Hung } \\
\text { Kuo }^{41}\end{array}$ & 240 & $80(33.3 \%)$ & NA & $\begin{array}{l}\text { DAA vs untreated: } \\
22(27.5 \%) \text { vs } 94(58.8 \%) \\
P<0.00 \text { I }\end{array}$ & $\begin{array}{l}\text { DAA vs untreated: } \\
\text { HR/RFA, n(\%) I5 } \\
(18.8) / 65(81.2) \text { vs } 58 \\
(36.3) / 102(63.7)\end{array}$ & $30.7 \pm 27.5$ months \\
\hline $\begin{array}{l}\text { Carmen } \\
\text { M Preda }\end{array}$ & 24 & $12(50 \%)$ & $\begin{array}{l}\text { DAA vs } \\
\text { NDAA: } \\
42 \text { vs } 28.5\end{array}$ & $\begin{array}{l}\text { DAA resection+RFA vs control resection } \\
\text { +RFA: } \\
21 \% \text { vs } 86 \% \mathrm{P}=0.002 \\
\text { Recurrence rates were calculated from } \\
\text { the initiation of DAA therapy to the time } \\
\text { of the abovementioned recurrence } \\
\text { events. }\end{array}$ & $\begin{array}{l}\text { DAA resection+RFA } \\
\text { vs control resection } \\
\text { +RFA } \\
\text { HR/RFA, } n(\%) \\
9(56.2 \%) / 7(43.8 \%)\end{array}$ & $23(7,72)$ months \\
\hline $\begin{array}{l}\text { Hiroko } \\
\text { Nagata }^{61}\end{array}$ & 143 & $83(58 \%)$ & $\begin{array}{l}\text { IFN vs } \\
\text { DAA: } \\
6.8 \text { y vs } \\
1.8 \text { y }\end{array}$ & $\begin{array}{l}\text { IFN vs DAA: } \\
54.2 \% \text { vs } 45.1 \% \mathrm{P}=0.54 \\
5 \text {-year incidence rate }\end{array}$ & NA & NA \\
\hline Kenji lkeda $^{62}$ & 178 & $89(50 \%)$ & $\begin{array}{l}20.7 \\
(7.0-26.2) \\
\text { months }\end{array}$ & $\begin{array}{l}\text { DAA vs NDAA: } \\
6 \text { months: } 2.2 \% \text { vs } 9.0 \% \\
\text { I year: } 18.1 \% \text { vs } 25 \% \\
2 \text { years: } 21.8 \% \text { vs } 46.5 \% \\
P=0.003\end{array}$ & $\begin{array}{l}\text { Surgery: } 43 \text { vs } 4 \text { I } \\
\text { RFA: } 38 \text { vs } 48 \\
\text { TACE: } 4 \text { vs } 0 \\
\text { PRT: } 4 \text { vs } 0\end{array}$ & $\begin{array}{l}\text { I0.7 months } \\
(0.8-22.2 \text { years })\end{array}$ \\
\hline
\end{tabular}

(Continued) 
Table I (Continued).

\begin{tabular}{|c|c|c|c|c|c|c|}
\hline Author & $\mathbf{N}$ & $\begin{array}{l}\text { N (\%) } \\
\text { Receiving } \\
\text { DAA }\end{array}$ & $\begin{array}{l}\text { Follow- } \\
\text { Up } \\
\text { (Months) }\end{array}$ & HCC Recurrence Rate & $\begin{array}{l}\text { Curative } \\
\text { Treatment }\end{array}$ & $\begin{array}{l}\text { Time Between } \\
\text { HCC Remission } \\
\text { and DAA Initiation } \\
\text { (Months) }\end{array}$ \\
\hline Kenji Imai $^{65}$ & 91 & $13(14.2)$ & 36 months & $\begin{array}{l}\text { DAA (I3) vs IFN (I4) vs untreated (64): } \\
\text { I-yr RFS: } 84.6 \% \text {; vs } 76.2 \% \text { vs } 76.2 \% \\
\text { 2-yr RFS: } 100 \% \text { vs } 69.2 \% \text { vs } 69.2 \% \\
\text { 3-yr RFS: } 76.8 \% \text { vs } 45.0 \% \text { vs } 22.4 \%\end{array}$ & $\begin{array}{l}\text { Surgery: NA } \\
\text { RFA: NA }\end{array}$ & NA \\
\hline Tsuda $Y^{39}$ & 36 & $36(100 \%)$ & 11.4 & $\begin{array}{l}9 / 36(25 \%) \\
\text { during the follow-up period }\end{array}$ & NA & NA \\
\hline TokoroM ${ }^{40}$ & 22 & $22(100 \%)$ & 16.2 & $\begin{array}{l}13 / 22(59 \%) \\
\text { during the follow-up period }\end{array}$ & NA & NA \\
\hline Urabe $A^{51}$ & 119 & $63(52.9 \%)$ & $\begin{array}{l}\text { IFN vs } \\
\text { DAA } \\
33.9 \text { vs } \\
10.9\end{array}$ & $\begin{array}{l}\text { IFN vs DAA: } \\
6 \text { months: } 16 \% \text { vs } 5 \% \\
\text { I2 months: } 31 \% \text { vs } 18 \% \\
\text { I8 months: } 36 \% \text { vs } 37 \% \\
P=0.54\end{array}$ & NA & $24.3 \pm 24.9$ \\
\hline Sangiovanni $A^{63}$ & 111 & $111(100 \%)$ & $\begin{array}{l}49 \text { weeks } \\
(4-116)\end{array}$ & $\begin{array}{l}31 / 1111(27.9 \%) \\
\text { during the follow-up period }\end{array}$ & NA & NA \\
\hline Ohki $\mathrm{T}^{64}$ & 60 & $20(33.3 \%)$ & 24 & $\begin{array}{l}\text { Untreated vs IFN vs DAA: } \\
55 \% \text { vs } 55 \% \text { vs } 35 \% \mathrm{P}=0.38 \\
\text { Recurrence within } 24 \text { months }\end{array}$ & RFA (100\%) & NA \\
\hline Granata $R^{52}$ & 36 & $36(100 \%)$ & $7(3-15)$ & $\begin{array}{l}10 / 36(27.8 \%) \\
\text { during the follow-up period }\end{array}$ & NA & NA \\
\hline Chan $Y^{31}$ & 37 & $14(37.8 \%)$ & $\begin{array}{l}\text { DAA vs } \\
\text { NDAA: } \\
23 \text { vs } 17\end{array}$ & $\begin{array}{l}\text { DAA vs NDAA: } \\
5 / 14(36 \%) \text { vs } 15 / 23(65 \%)\end{array}$ & NA & $\begin{array}{l}\text { II months (range, } 2 \\
\text { to } 17 \text { months) }\end{array}$ \\
\hline Minami $\mathrm{T}^{27}$ & 163 & $163(100 \%)$ & $\begin{array}{l}14.5 \\
(2.1-30.9)\end{array}$ & $\begin{array}{l}12 \text { months: } 38 \% \\
24 \text { months: } 54.5 \%\end{array}$ & $\begin{array}{l}\text { Resection: } 14 \\
\text { Ablation: } 147 \\
\text { Radiotherapy: I } \\
\text { TACE: I }\end{array}$ & $\begin{array}{l}3.9 \text { y (range, } \\
0.03-18.8 \text { y) } \\
\text { between the initial } \\
\text { HCC diagnosis and } \\
\text { the initiation of DAAs }\end{array}$ \\
\hline Shinichiro $N^{55}$ & 312 & $312(100 \%)$ & 855 days & $\begin{array}{l}\text { I year: } 18.3 \% \\
2 \text { years: } 38.8 \% \\
3 \text { years: } 55.4 \%\end{array}$ & $\begin{array}{l}\text { Resection: } 89 \\
\text { Ablation: } 223\end{array}$ & 297 days \\
\hline $\begin{array}{l}\text { Elisabetta } \\
\text { Degasperi }^{30}\end{array}$ & 60 & $312(100 \%)$ & $23(7-37)$ & $\begin{array}{l}6 \text { months: } 7 \% \\
12 \text { months: } 17 \% \\
18 \text { months: } 27 \% \\
36 \text { months: } 43 \%\end{array}$ & $\begin{array}{l}\text { RFA: } 4 \text { I (68) } \\
\text { Resection: I3 (22) } \\
\text { PEI: I (2) } \\
\text { TACE: } 5 \text { (8) }\end{array}$ & $12(4-163)$ months \\
\hline
\end{tabular}

overcome their increased risk of liver cancer recurrence. A multicenter study from Europe has shown that $19 \%$ of patients with advanced liver disease waiting for liver transplantation were delisted due to clinical improvement after DAA treatment, confirming that viral suppression by DAA may result in liver function and prognosis improvement. ${ }^{85}$ Furthermore, after the advent of DAA since 2011, the number of HCV patients registered for liver transplantation has been reduced. ${ }^{86}$ These studies were consistent with previous literature reporting that DAA therapy improves liver 
function. ${ }^{87-90}$ and hepatic decompensation, ${ }^{87,88}$ excessively delaying DAA therapy that might lead to the deterioration of liver function and undesirable prognosis.

Compared with other viruses and risk factors, patients infected with $\mathrm{HCV}$ tended to have a higher rate of $\mathrm{HCC}$ occurrence, indicating that the impact of DAA therapy on long-term outcomes in this population is vital. The optimum time of anti-HCV treatment in patients with HCC remains debatable. Therefore, providers need to remain vigilant and inform patients who even if they achieve SVR after antiviral treatment, they still have the risk of HCC recurrence and require regular follow-up.

\section{Funding}

The study was sponsored by Chinese Foundation for Hepatitis Prevention and Control-TianQing liver disease research fund subject (TQGB2020D118).

\section{Disclosure}

The authors declare no conflicts of interest.

\section{References}

1. World Health Organaization. Cancer. September 12, 2018.

2. European Association For The Study Of The Liver. EASL-EORTC clinical practice guidelines: management of hepatocellular carcinoma. J Hepatol. 2012;56(4):908-943. doi:10.1016/j.jhep.20 11.12 .001

3. World Health Organaization. Hepatitis C. July 27, 2020.

4. Hoshida Y, Fuchs BC, Bardeesy N, et al. Pathogenesis and prevention of hepatitis C virus-induced hepatocellular carcinoma. $J$ Hepatol. 2014;61(1 Suppl):S79-90. doi:10.1016/j.jhep.2014.07.010

5. Ikeda K, Arase Y, Saitoh S, et al. Interferon beta prevents recurrence of hepatocellular carcinoma after complete resection or ablation of the primary tumor-A prospective randomized study of hepatitis C virus-related liver cancer. Hepatology. 2000;32(2):228-232. doi:10.1053/jhep.2000.9409

6. Kiyosawa K, Umemura T, Ichijo T, et al. Hepatocellular carcinoma: recent trends in Japan. Gastroenterology. 2004;127(Suppl 5):S17-26. doi:10.1053/j.gastro.2004.09.012

7. Poon RT-P, Fan S-T, Lo C-M, et al. Intrahepatic recurrence after curative resection of hepatocellular carcinoma: long-term results of treatment and prognostic factors. Ann Surg. 1999;229(2):216-222. doi:10.1097/00000658-199902000-00009

8. Cabibbo G, Petta S, Barbàra M, et al. A meta-analysis of single $\mathrm{HCV}$-untreated arm of studies evaluating outcomes after curative treatments of HCV-related hepatocellular carcinoma. Liver Int 2017;37(8):1157-1166. doi:10.1111/liv.13357

9. Morgan RL, Baack B, Smith BD, et al. Eradication of hepatitis $\mathrm{C}$ virus infection and the development of hepatocellular carcinoma: a meta-analysis of observational studies. Ann Intern Med. 2013;158(5 Pt 1):329-337. doi:10.7326/0003-4819-158-5-201303050-00005

10. Veldt BJ, Heathcote EJ, Wedemeyer H, et al. Sustained virologic response and clinical outcomes in patients with chronic hepatitis C and advanced fibrosis. Ann Intern Med. 2007;147(10):677-684. doi:10.7326/0003-4819-147-10-200711200-00003
11. Kobayashi M, Suzuki F, Fujiyama S, et al. Sustained virologic response by direct antiviral agents reduces the incidence of hepatocellular carcinoma in patients with $\mathrm{HCV}$ infection. $J$ Med Virol. 2017;89(3):476-483. doi:10.1002/jmv.24663

12. Attar BM, Van Thiel DH. Hepatitis C virus: a time for decisions. Who should be treated and when? World J Gastrointest Pharmacol Ther. 2016;7(1):33-40. doi:10.4292/wjgpt.v7.i1.33

13. Afdhal N, Zeuzem S, Kwo P, et al. Ledipasvir and sofosbuvir for untreated HCV genotype 1 infection. $N$ Engl J Med. 2014;370 (20):1889-1898. doi:10.1056/NEJMoa1402454

14. Charlton M, Everson GT, Flamm SL, et al. Ledipasvir and sofosbuvir plus ribavirin for treatment of $\mathrm{HCV}$ infection in patients with advanced liver disease. Gastroenterology. 2015;149(3):649-659. doi:10.1053/j.gastro.2015.05.010

15. Leroy V, Angus P, Bronowicki J-P, et al. Daclatasvir, sofosbuvir, and ribavirin for hepatitis $\mathrm{C}$ virus genotype 3 and advanced liver disease: a randomized Phase III study (ALLY-3+). Hepatology. 2016;63 (5):1430-1441. doi:10.1002/hep.28473

16. Zoulim F, Liang TJ, Gerbes AL, et al. Hepatitis C virus treatment in the real world: optimising treatment and access to therapies. Gut. 2015;64(11):1824-1833. doi:10.1136/gutjnl-2015-310421

17. Shiha G, Mousa N, Soliman R, et al. Incidence of HCC in chronic hepatitis $\mathrm{C}$ patients with advanced hepatic fibrosis who achieved SVR following DAAs: a prospective study. J Viral Hepat. 2020;27 (7):671-679. doi:10.1111/jvh.13276

18. Singal AG, Lim JK, Kanwal F. AGA clinical practice update on interaction between oral direct-acting antivirals for chronic hepatitis $\mathrm{C}$ infection and hepatocellular carcinoma: expert review. Gastroenterology. 2019;156 (8):2149-2157. doi:10.1053/j.gastro.2019.02.046

19. Reig M, Mariño Z, Perelló C, et al. Unexpected high rate of early tumor recurrence in patients with HCV-related HCC undergoing interferon-free therapy. J Hepatol. 2016;65(4):719-726. doi:10.1016/j. jhep.2016.04.008

20. Tsai P-C, Huang C-F, Yu M-L. Unexpected early tumor recurrence in patients with hepatitis $\mathrm{C}$ virus-related hepatocellular carcinoma undergoing interferon-free therapy: issue of the interval between HCC treatment and antiviral therapy. $J$ Hepatol. 2017;66(2):464. doi:10.1016/j.jhep.2016.10.035

21. Singal AG, Rich NE, Mehta N, et al. Direct-acting antiviral therapy not associated with recurrence of hepatocellular carcinoma in a multicenter north american cohort study. Gastroenterology. 2019;156(6):1683-1692. doi:10.1053/j.gastro.2019.01.027

22. Zavaglia $\mathrm{C}$, Okolicsanyi $\mathrm{S}$, Cesarini $\mathrm{L}$, et al. Is the risk of neoplastic recurrence increased after prescribing direct-acting antivirals for HCV patients whose HCC was previously cured? J Hepatol. 2017;66(1):236-237. doi:10.1016/j.jhep.2016.08.016

23. Ogawa E, Furusyo N, Nomura H, et al. Short-term risk of hepatocellular carcinoma after hepatitis $\mathrm{C}$ virus eradication following direct-acting anti-viral treatment. Aliment Pharmacol Ther. 2018;47 (1):104-113. doi:10.1111/apt.14380

24. Singal AG, Rich NE, Mehta N, et al. Direct-acting antiviral therapy for hepatitis $\mathrm{C}$ virus infection is associated with increased survival in patients with a history of hepatocellular carcinoma. Gastroenterology. 2019;157(5):1253-1263.

25. Saraiya N, Yopp AC, Rich NE, et al. Systematic review with meta-analysis: recurrence of hepatocellular carcinoma following direct-acting antiviral therapy. Aliment Pharmacol Ther. 2018;48 (2):127-137. doi:10.1111/apt.14823

26. Adhoute X, Penaranda G, Raoul JL, et al. Hepatocellular carcinoma recurrence in hepatitis $\mathrm{C}$ virus-related cirrhosis treated with direct-acting antivirals: a case-control study. Eur $J$ Gastroenterol Hepatol. 2018;30(4):368-375. doi:10.1097/MEG.0000000000001082

27. Minami T, Wake T, Nishibatake M, et al. Hepatocellular carcinoma recurrence after curative treatments in patients with chronic hepatitis $\mathrm{C}$ who underwent direct-acting antiviral therapy. Hepatology. 2017;66:760A-761A. 
28. Kolly P, Waidmann O, Vermehren J, et al. Hepatocellular carcinoma recurrence after direct antiviral agent treatment: a European multicentric study. J Hepatol. 2017;66:S621. doi:10.1016/S0168-8278(17) 31686-0

29. Kogiso T, Sagawa T, Kodama K, et al. Hepatocellular carcinoma after direct-acting antiviral drug treatment in patients with hepatitis $\mathrm{C}$ virus. JGH Open. 2019;3(1):52-60. doi:10.1002/jgh3.12105

30. Degasperi E, D'Ambrosio R, Iavarone $M$, et al. Factors associated with increased risk of de novo or recurrent hepatocellular carcinoma in patients with cirrhosis treated with direct-acting antivirals for $\mathrm{HCV}$ infection. Clin Gastroenterol Hepatol. 2019;17(6):1183-1191. doi:10.1016/j.cgh.2018.10.038

31. Chan Y, Maclennan S, Dixon E, et al. Direct-acting antivirals are not associated with early tumor recurrence after curative treatments in hepatitis C-related hepatocellular carcinoma. $\mathrm{Am}$ $J$ Gastroenterol. 2017;112:S521-S523. doi:10.14309/00000434201710001-00931

32. Persico M, Aglitti A, Aghemo A, et al. High efficacy of direct-acting anti-viral agents in hepatitis $\mathrm{C}$ virus-infected cirrhotic patients with successfully treated hepatocellular carcinoma. Aliment Pharmacol Ther. 2018;47(12):1705-1712. doi:10.1111/apt.14685

33. Cabibbo G, Celsa C, Calvaruso V, et al. Direct-acting antivirals after successful treatment of early hepatocellular carcinoma improve survival in HCV-cirrhotic patients. J Hepatol. 2019;71(2):265-273. doi:10.1016/j.jhep.2019.03.027

34. Huang AC, Mehta N, Dodge JL, et al. Direct-acting antivirals do not increase the risk of hepatocellular carcinoma recurrence after local-regional therapy or liver transplant waitlist dropout. Hepatology. 2018;68(2):449-461. doi:10.1002/hep.29855

35. Gorgen A, Galvin Z, Huang AC, et al. The impact of direct acting antivirals on overall mortality and tumoral recurrence in patients with hepatocellular carcinoma listed for liver transplantation.: an international multicenter study. Transplantation. 2020;104:2087-2096. doi:10.1097/TP.0000000000003115

36. Worns MA, Galle PR, Zeuzem S, et al. Drug treatment for chronic hepatitis $\mathrm{C}$ infection and cancer risk: the effect of direct antivirals on the incidence and recurrence of hepatocellular carcinoma. Dtsch Arztebl Int. 2017;114(35-36):597-602.

37. Conti F, Buonfiglioli F, Scuteri A, et al. Early occurrence and recurrence of hepatocellular carcinoma in HCV-related cirrhosis treated with direct-acting antivirals. $J$ Hepatol. 2016;65(4):727-733. doi:10.1016/j.jhep.2016.06.015

38. Warzyszynska K, Jonas M, Wasiak D, et al. Accelerated hepatocellular carcinoma recurrence rate after postoperative direct-acting antivirals treatment - preliminary report. Clin Exp Hepatol. 2017;3 (4):194-197. doi:10.5114/ceh.2017.71483

39. Tsuda Y, Nakmura K, Yokohama K, Ohama H, Sujishi T, Tsuchimoto T. The effect of interferon-free therapy on tumor recurrence in $\mathrm{HCV}$ patients with treatment history of hepatocellular carcinoma. Hepatology. 2016;64:666A-667A.

40. Tokoro M, Iwao M, Arakawa M, et al. The features of hepatocellular carcinoma after IFN free treatment. Hepatology. 2016;64:671A.

41. Kuo YH, Wang J-H, Chang K-C, et al. The influence of direct-acting antivirals in hepatitis $\mathrm{C}$ virus related hepatocellular carcinoma after curative treatment. Invest New Drugs. 2020;38(1):202-210. doi:10.1007/s10637-019-00870-9

42. Cabibbo G, Petta S, Calvaruso V, et al. Is early recurrence of hepatocellular carcinoma in HCV cirrhotic patients affected by treatment with direct-acting antivirals? A prospective multicentre study. Aliment Pharmacol Ther. 2017;46(7):688-695. doi:10.1111/ apt. 14256

43. The AN. Lack of evidence of an effect of direct-acting antivirals on the recurrence of hepatocellular carcinoma: data from three ANRS cohorts. J Hepatol. 2016;65(4):734-740. doi:10.1016/j. jhep.2016.05.045
44. Lin WC, Lin Y-S, Chang C-W, et al. Impact of direct-acting antiviral therapy for hepatitis C-related hepatocellular carcinoma. PLoS One. 2020;15(5):e0233212. doi:10.1371/journal.pone.0233212

45. Mashiba T, Joko K, Kurosaki M, et al. Does interferon-free direct-acting antiviral therapy for hepatitis $\mathrm{C}$ after curative treatment for hepatocellular carcinoma lead to unexpected recurrences of HCC? A multicenter study by the Japanese Red Cross Hospital Liver Study Group. PLoS One. 2018;13(4):e0194704. doi:10.1371/journal. pone. 0194704

46. Miuma S, Miyamoto J, Taura N, et al. Influence of interferon-free direct-acting antiviral therapy on primary hepatocellular carcinoma recurrence: a landmark time analysis and time-dependent extended cox proportional hazards model analysis. Intern Med. 2020;59 (7):901-907. doi:10.2169/internalmedicine.3382-19

47. Saito T, Chiba T, Suzuki E, et al. Effect of previous interferon-based therapy on recurrence after curative treatment of hepatitis C virus-related hepatocellular carcinoma. Int J Med Sci. 2014;11 (7):707-712. doi:10.7150/ijms.8764

48. Hagihara H, Nouso K, Kobayashi Y, et al. Effect of pegylated interferon therapy on intrahepatic recurrence after curative treatment of hepatitis C virus-related hepatocellular carcinoma. Int J Clin Oncol. 2011;16(3):210-220. doi:10.1007/s10147-010-0150-x

49. Shiratori Y, Shiina S, Teratani T, et al. Interferon therapy after tumor ablation improves prognosis in patients with hepatocellular carcinoma associated with hepatitis C virus. Ann Intern Med. 2003;138 (4):299-306. doi:10.7326/0003-4819-138-4-200302180-00008

50. Miyatake H, Kobayashi Y, Iwasaki Y, et al. Effect of previous interferon treatment on outcome after curative treatment for hepatitis C virus-related hepatocellular carcinoma. Dig Dis Sci. 2012;57 (4):1092-1101. doi:10.1007/s10620-011-1934-1

51. Urabe A, Sakamori R, Tatsumi T, et al. Effects of IFN-free therapy for hepatitis $\mathrm{C}$ virus after hepatocellular carcinoma treatment on early HCC recurrence compared to IFN-based therapy. Hepatology. 2017;66:843A-844A.

52. Granata R, Di Costanzo GG, Zamparelli M, Guarino M, Cordone G, Tortora R. Hepatocellular carcinoma recurrence rate in $\mathrm{HCV}$ infected patients treated with direct antiviral agents. A single center experience. $J$ Hepatol. 2017;66(1):S717. doi:10.1016/S01688278(17)31918-9

53. Joko K, Kurosaki M, Ochi H, Izumi N. Does Interfeon-free direct-acting antiviral therapy for hepatitis $\mathrm{C}$ lead to unexpected recurrences of hepatocellular carcinoma? Real-world nation-wide multicenter study by the Japanese Red Cross Hospital Liver Study Group. Hepatology. 2017;66:742A.

54. Waziry R, Hajarizadeh B, Grebely J, et al. Hepatocellular carcinoma risk following direct-acting antiviral $\mathrm{HCV}$ therapy: a systematic review, meta-analyses, and meta-regression. J Hepatol. 2017;67 (6):1204-1212. doi:10.1016/j.jhep.2017.07.025

55. Nakamura S, Nouso K, Okada H, et al. Hepatocellular carcinoma recurrence in $\mathrm{HCV}$ patients treated with direct-acting antivirals after curative treatment. Hepatoma Research. 2019;5:16.

56. Kolly P, Waidmann O, Vermehren J, et al. Hepatocellular carcinoma recurrence after direct antiviral agent treatment: a European multicentre study. J Hepatol. 2017;67(4):876-878. doi:10.1016/j.jhep.2017.07.007

57. Torres HA, Vauthey J-N, Economides MP, et al. Hepatocellular carcinoma recurrence after treatment with direct-acting antivirals: first, do no harm by withdrawing treatment. J Hepatol. 2016;65 (4):862-864. doi:10.1016/j.jhep.2016.05.034

58. Petta S, Cabibbo G, Barbara M, et al. Hepatocellular carcinoma recurrence in patients with curative resection or ablation: impact of HCV eradication does not depend on the use of interferon. Aliment Pharmacol Ther. 2017;45(1):160-168. doi:10.1111/apt.13821

59. Virlogeux V, Pradat P, Hartig-Lavie K, et al. Direct-acting antiviral therapy decreases hepatocellular carcinoma recurrence rate in cirrhotic patients with chronic hepatitis C. Liver Int. 2017;37 (8):1122-1127. doi:10.1111/liv.13456 
60. Preda CM, Baicus C, Sandra I, et al. Recurrence rate of hepatocellular carcinoma in patients with treated hepatocellular carcinoma and hepatitis C virus-associated cirrhosis after ombitasvir/paritaprevir/ritonavir +dasabuvir+ribavirin therapy. United European Gastroenterol J. 2019;7(5):699-708. doi:10.1177/2050640619841254

61. Nagata H, Nakagawa M, Asahina Y, et al. Effect of interferon-based and -free therapy on early occurrence and recurrence of hepatocellular carcinoma in chronic hepatitis C. J Hepatol. 2017;67 (5):933-939. doi:10.1016/j.jhep.2017.05.028

62. Ikeda K, Kawamura Y, Kobayashi M, et al. Direct-acting antivirals decreased tumor recurrence after initial treatment of hepatitis C virus-related hepatocellular carcinoma. Dig Dis Sci. 2017;62 (10):2932-2942. doi:10.1007/s10620-017-4739-z

63. Sangiovanni A, Biganzoli E, Borgio G, et al. IFN-free DAA treatment of cirrhotic HCV patients with or without history of HCC: a multi-center prospective trial in Italy. Hepatology. 2017;66:734A-735A.

64. Ohki T, Goto E, Sato T, et al. Direct acting antiviral therapy after curative treatment of hepatocellular carcinoma improved recurrence free survival rate. Hepatology. 2017;66:759A.

65. Imai K, Takai K, Hanai T, et al. Sustained virological response by direct-acting antivirals reduces the recurrence risk of hepatitis C-related hepatocellular carcinoma after curative treatment. Mol Clin Oncol. 2020;12(2):111-116.

66. Lawitz E, Sulkowski MS, Ghalib R, et al. Simeprevir plus sofosbuvir, with or without ribavirin, to treat chronic infection with hepatitis $\mathrm{C}$ virus genotype 1 in non-responders to pegylated interferon and ribavirin and treatment-naive patients: the COSMOS randomised study. Lancet. 2014;384(9956):1756-1765. doi:10.1016/S01406736(14)61036-9

67. Sulkowski MS, Gardiner DF, Rodriguez-Torres M, et al. Daclatasvir plus sofosbuvir for previously treated or untreated chronic HCV infection. $N$ Engl $J$ Med. 2014;370(3):211-221. doi:10.1056/ NEJMoa1306218

68. Kowdley KV, Gordon SC, Reddy KR, et al. Ledipasvir and sofosbuvir for 8 or 12 weeks for chronic HCV without cirrhosis. $N$ Engl J Med. 2014;370(20):1879-1888. doi:10.1056/NEJMoa1402355

69. EI Braks R, Ganne-Carrié N, Fontaine H, et al. Effect of sustained virological response on long-term clinical outcome in 113 patients with compensated hepatitis C-related cirrhosis treated by interferon alpha and ribavirin. World J Gastroenterol. 2007;13(42):5648-5653. doi:10.3748/wjg.v13.i42.5648

70. Bruno S, Crosignani A, Maisonneuve P, et al. Hepatitis C virus genotype $1 \mathrm{~b}$ as a major risk factor associated with hepatocellular carcinoma in patients with cirrhosis: a seventeen-year prospective cohort study. Hepatology. 2007;46(5):1350-1356. doi:10.1002/ hep. 21826

71. Cardoso A-C, Moucari R, Figueiredo-Mendes C, et al. Impact of peginterferon and ribavirin therapy on hepatocellular carcinoma: incidence and survival in hepatitis $\mathrm{C}$ patients with advanced fibrosis. $J$ Hepatol. 2010;52(5):652-657. doi:10.1016/j. jhep.2009.12.028

72. Kozbial K, Moser S, Schwarzer R, et al. Unexpected high incidence of hepatocellular carcinoma in cirrhotic patients with sustained virologic response following interferon-free direct-acting antiviral treatment. $J$ Hepatol. 2016;65(4):856-858. doi:10.1016/j. jhep.2016.06.009

73. Cardoso H, Vale AM, Rodrigues S, et al. High incidence of hepatocellular carcinoma following successful interferon-free antiviral therapy for hepatitis C associated cirrhosis. J Hepatol. 2016;65 (5):1070-1071. doi:10.1016/j.jhep.2016.07.027
74. Waziry R, Grebely J, Amin J, et al. Trends in hepatocellular carcinoma among people with $\mathrm{HBV}$ or $\mathrm{HCV}$ notification in Australia (2000-2014). J Hepatol. 2016;65(6):1086-1093. doi:10.1016/j. jhep.2016.08.010

75. Yoshida H, Shiratori Y, Moriyama M, et al. Interferon therapy reduces the risk for hepatocellular carcinoma: national surveillance program of cirrhotic and noncirrhotic patients with chronic hepatitis $\mathrm{C}$ in Japan. IHIT study group. Inhibition of hepatocarcinogenesis by interferon therapy. Ann Intern Med. 1999;131(3):174-181. doi:10.7326/0003-4819-131-3-199908030-00003

76. Bielen R, Moreno C, Van Vlierberghe H, et al. The risk of early occurrence and recurrence of hepatocellular carcinoma in hepatitis $\mathrm{C}$-infected patients treated with direct-acting antivirals with and without pegylated interferon: a Belgian experience. $J$ Viral Hepat. 2017;24(11):976-981. doi:10.1111/jvh.12726

77. Collins JM, Raphael KL, Terry C, et al. Hepatitis B virus reactivation during successful treatment of hepatitis $\mathrm{C}$ virus with sofosbuvir and simeprevir. Clin Infect Dis. 2015;61(8):1304-1306. doi:10.1093/cid/ civ474

78. De Monte A, Courjon J, Anty R, et al. Direct-acting antiviral treatment in adults infected with hepatitis $C$ virus: reactivation of hepatitis $\mathrm{B}$ virus coinfection as a further challenge. $J$ Clin Virol. 2016;78:27-30. doi:10.1016/j.jcv.2016.02.026

79. Takayama H, Sato T, Ikeda F, et al. Reactivation of hepatitis B virus during interferon-free therapy with daclatasvir and asunaprevir in patient with hepatitis B virus/hepatitis C virus co-infection. Hepatol Res. 2016;46(5):489-491. doi:10.1111/hepr.12578

80. Nagaoki Y, Aikata H, Miyaki D, et al. Clinical features and prognosis in patients with hepatocellular carcinoma that developed after hepatitis C virus eradication with interferon therapy. $J$ Gastroenterol. 2011;46(6):799-808. doi:10.1007/s00535-011-0384-z

81. Kim SR, Matsuoka T, Maekawa Y, et al. Development of multicentric hepatocellular carcinoma after completion of interferon therapy. $J$ Gastroenterol. 2002;37(8):663-668. doi:10.1007/s005350200106

82. Shindo M, Hamada K, Oda Y, et al. Long-term follow-up study of sustained biochemical responders with interferon therapy. Hepatology. 2001;33(5):1299-1302. doi:10.1053/jhep.2001.24100

83. Ikeda M, Fujiyama S, Tanaka M, et al. Risk factors for development of hepatocellular carcinoma in patients with chronic hepatitis $\mathrm{C}$ after sustained response to interferon. $J$ Gastroenterol. 2005;40 (2):148-156. doi:10.1007/s00535-004-1519-2

84. Toyoda H, Kumada T, Tokuda A, et al. Long-term follow-up of sustained responders to interferon therapy, in patients with chronic hepatitis C. J Viral Hepat. 2000;7(6):414-419. doi:10.1046/j.13652893.2000.00241.x

85. Belli LS, Berenguer M, Cortesi PA, et al. Delisting of liver transplant candidates with chronic hepatitis $\mathrm{C}$ after viral eradication: a European study. J Hepatol. 2016;65(3):524-531. doi:10.1016/j.jhep.2016.05.010

86. Yang JD, Larson JJ, Watt KD, et al. Hepatocellular carcinoma is the most common indication for liver transplantation and placement on the waitlist in the United States. Clin Gastroenterol Hepatol. 2017;15 (5):767-775. doi:10.1016/j.cgh.2016.11.034

87. Cheung MCM, Walker AJ, Hudson BE, et al. Outcomes after successful direct-acting antiviral therapy for patients with chronic hepatitis C and decompensated cirrhosis. J Hepatol. 2016;65(4):741-747. doi:10.1016/j.jhep.2016.06.019

88. Foster GR, Irving WL, Cheung MCM, et al. Impact of direct acting antiviral therapy in patients with chronic hepatitis $\mathrm{C}$ and decompensated cirrhosis. J Hepatol. 2016;64(6):1224-1231. doi:10.1016/j. jhep.2016.01.029 
89. Manns M, Samuel D, Gane EJ, et al. Ledipasvir and sofosbuvir plus ribavirin in patients with genotype 1 or 4 hepatitis $\mathrm{C}$ virus infection and advanced liver disease: a multicentre, open-label, randomised, phase 2 trial. Lancet Infect Dis. 2016;16(6):685-697. doi:10.1016/ S1473-3099(16)00052-9
90. Poordad F, Schiff ER, Vierling JM, et al. Daclatasvir with sofosbuvir and ribavirin for hepatitis $\mathrm{C}$ virus infection with advanced cirrhosis or post-liver transplantation recurrence. Hepatology. 2016;63 (5):1493-1505. doi:10.1002/hep.28446

\section{Publish your work in this journal}

The Journal of Hepatocellular Carcinoma is an international, peerreviewed, open access journal that offers a platform for the dissemination and study of clinical, translational and basic research findings in this rapidly developing field. Development in areas including, but not limited to, epidemiology, vaccination, hepatitis therapy, pathology and molecular tumor classification and prognostication are all considered for publication. The manuscript management system is completely online and includes a very quick and fair peer-review system, which is all easy to use. Visit http://www.dovepress.com/ testimonials.php to read real quotes from published authors. 